\title{
Two mammalian helix-loop-helix factors structurally related to Drosophila hairy and Enhancer of split
}

\author{
Yoshiki Sasai, ${ }^{1}$ Ryoichiro Kageyama, ${ }^{1,3}$ Yoshiaki Tagawa, ${ }^{1}$ Ryuichi Shigemoto, ${ }^{2}$ \\ and Shigetada Nakanishi ${ }^{1}$ \\ ${ }^{1}$ Institute for Immunology and ${ }^{2}$ Department of Morphological Brain Science, Kyoto University Faculty of Medicine, \\ Kyoto 606, Japan
}

\begin{abstract}
We report the molecular characterization of two novel rat helix-loop-helix (HLH) proteins, designated HES-1 and HES-3, that show structural homology to the Drosophila hairy and Enhancer of split $[E($ spl $)]$ proteins, both of which are required for normal neurogenesis. HES-1 mRNA, expressed in various tissues of both embryos and adults, is present at a high level in the epithelial cells, including the embryonal neuroepithelial cells, as well as in the mesoderm-derived tissues such as the embryonal muscle. In contrast, HES-3 mRNA is produced exclusively in cerebellar Purkinje cells. HES-1 represses transcription by binding to the $\mathbf{N}$ box, which is a recognition sequence of $E(s p l)$ proteins. Interestingly, neither HES-1 nor HES-3 alone interacts efficiently with the $E$ box, but each protein decreases the transcription induced by E-box-binding HLH activators such as E47. Furthermore, HES-1 also inhibits the functions of MyoD and MASH1 and effectively diminishes the myogenic conversion of C3H10T1/2 cells induced by MyOD. These results suggest that HES-1 may play an important role in mammalian development by negatively acting on the two different sequences while HES-3 acts as a repressor in a specific type of neurons.
\end{abstract}

[Key Words: Helix-loop-helix proteins; repressor; hairy; Enhancer of split; neuroepithelium; Purkinje cell] Received July 14, 1992; revised version accepted October 12, 1992.

Our understanding of the basic mechanisms of vertebrate cell differentiation has been greatly advanced by the findings of transcription factors such as helix-loophelix (HLH), homeo box, and POU domain proteins (Gehring 1987; Tapscott et al. 1988; De Robertis et al. 1990; Rosenfeld 1991). However, our knowledge of factors involved in mammalian development is still limited compared with our knowledge of the Drosophila system, in which various genetic analyses are available.

Recent studies suggest that Drosophila and mammals may share, at least in part, some similar mechanisms for tissue differentiation; thus, Drosophila studies give us useful clues to investigate the complex mechanisms of mammalian development. For example, new insights into the molecular nature of mammalian development have emerged from analyses of the Pax gene family, mouse genes related to Drosophila paired box genes (Kessel and Gruss 1990|. Pax genes are expressed with a distinct spatiotemporal pattern and are involved in several mouse and human genetic diseases (Gruss and Walther 1992). undulated, a mutation affecting the development of the mouse skeleton, is caused by a single amino acid change in the paired box of Paxl (Balling et al. 1988).

\footnotetext{
${ }^{3}$ Corresponding author.
}

Another striking example concerns MASHl, a rat factor homologous to the Drosophila achaete-scute complex (AS-C), that is specifically expressed in neuronal precursors (Johnson et al. 1990; Lo et al. 1991). In Drosophila, AS-C is essential at the level of neuronal precursor formation (Jan and Jan 1990); thus, MASH1 is suggested to be involved in mammalian neural development.

Here, to analyze novel HLH proteins responsible for mammalian development including neural differentiation, we attempted cDNA cloning of rat factors by the polymerase chain reaction (PCR) using primers corresponding to the conserved amino acid sequences in the HLH regions of the Drosophila hairy $(h)$ and Enhancer of split $[E(s p l)]$ proteins. The Drosophila $h$ gene, one of the pair-rule segmentation genes, is required at two different developmental stages: at the formation of alternate embryonic segments in early development and at normal neurogenesis in late development (Ingham et al. 1985; Rushlow et al. 1989; Jan and Jan 1990|. It has been suggested that the late $h$ function involves suppression of the achaete $(a c)$ gene of the AS-C, thus controlling the number of sensory organs (Botas et al. 1982; Villares and Cabrera 1987; Skeath and Carroll 1991). The $h$ protein has a basic HLH (B-HLH) domain (Rushlow et al. 1989), which is necessary for DNA binding and dimerization (Murre et al. 1989; Davis et al. 1990). In the B-HLH do- 
main, $h$ shows a high homology to $m 5, m 7$, and $m 8$ of E(spl), neurogenic genes (Klämbt et al. 1989; CamposOrtega and Knust 1990).

In this study we show the molecular cloning and characterization of two novel rat HLH factors, designated HES- 1 and HES-3. We describe their spatial and temporal expression patterns focusing on late embryonic and postnatal development, and characterize their transcriptional functions. Furthermore, we show that HES-1 inhibits the myogenic conversion of C3H10T1/2(10T1/2) cells induced by MyoD.

\section{Results}

\section{Isolation of novel HLH factors by PCR}

To isolate novel HLH factors expressed in the mammalian nervous system, we amplified cDNAs from rat whole embryos and adult nervous tissues by PCR using degenerate oligonucleotide primers (Lee et al. 1988; Saiki et al. 1988). The primers were designed on the basis of the consensus sequence of the B-HLH domains of the Drosophila $h$ and $E(s p l)$ proteins, as shown in Figure 1. We isolated four closely related but distinct clones and named the deduced amino acid sequences HES-1, HES-2, HES-3, and HES-4, according to their sequence homologies to the $h$ and $E(s p l \mid)$ gene products. The HES-3 clone was obtained from adult brain CDNA, and the other clones were isolated from embryo cDNA. HES-1 had the highest homology to the Drosophila $h$ protein throughout the amplified region, whereas the other three showed high homology only in the helix regions and much lower homology in the loop region (Fig. 1). All four clones showed higher sequence homology to $h$ than to $E(s p l)$, with the overall homologies of HES-1, HES-2, HES-3, and HES- 4 to $h$ in the amplified regions being $81 \%, 59 \%$, $51 \%$, and $46 \%$, respectively. We chose two factors, HES- 1 and HES-3, for further analysis and obtained their full-length cDNA clones.

\section{Structural analyses of HES-1 and HES-3}

HES-1 cDNA encoded a protein of 281 amino acid resi-

\begin{tabular}{|c|c|c|c|}
\hline & & S'primer & \\
\hline$E(s p I)$ & $\mathrm{m} 8$ & RRARMNKCLDNLKTLVAELRGDDG_I LRMDKAEMLE & \\
\hline$E(s p 1)$ & m5 & RRARMNKCIDTLKTLVAEFQGDDA ILRMDKAEMLE & gidenuly \\
\hline$E(s p l)$ & $m 7$ & RRAR INKCLDELKDLMAECVAQTG DAKFEKAD ILE & 10 hatry \\
\hline hatry & & $\begin{array}{l}\text { RRAR INNC LNELKTLI ILDATKKDP ARHSKL EKADILE } \\
1|1| \mid\end{array}$ & 100 \\
\hline HES -1 & & RRAR INESISQLKTI I LDALKKDSSRHSKLEKAD ILE & 81 \\
\hline HES -2 & & RRAR INESISQLKGLVLPLLGAET SRYSKLEKA & 59 \\
\hline HES -3 & & RRAR INLSIEQLRSLL_ERHYSHQIRKRKLEKADILE & 51 \\
\hline HES -4 & & RRARTNSSIKQLRMLL_EKEFQRHQPNSKLEKADILE & 46 \\
\hline
\end{tabular}

Figure 1. Strategy and results of PCR experiments. The deduced amino acid sequences of four HES partial clones and comparison of HES, $h$, and $E(s p l)$ proteins are shown. PCR was performed using degenerate primers indicated by arrows above the corresponding regions. Amino acid residues conserved among HES, $h$, and $E(s p l)$ proteins are depicted by bold letters, and the identical residues between HES- 1 and $h$ are connected by vertical bars. Percent $(\%)$ identity to $h$ is shown at right. dues, and the calculated molecular mass was $29.6 \mathrm{kD}$ (Fig. 2A). This protein showed $77 \%$ homology to the $h$ gene product in the putative B-HLH domain (amino acid residues $33-92$ ) and $43 \%$ homology in the downstream region (93-146) (boxed residues in Fig. 3A). Another feature, the proline residue, present in the basic region of $h$ and $E(s p l \mid$ was also conserved in the corresponding position of HES-1 (amino acid residue 40) (indicated by the asterisk in Fig. 3B).

HES-3 cDNA encoded a protein of 175 amino acid residues, and the calculated molecular mass was $19.1 \mathrm{kD}$ (Fig. 2B). The HES-3 protein showed $\sim 50 \%$ homology to the $h$ gene product in the B-HLH domain. The first methionine codon was present at nucleotide 1; thus, this protein lacked the amino-terminal half of the basic region (see also Fig. 3A). To avoid cloning artifacts, we investigated the sequences of three more independent cDNA clones of HES-3, but all had an in-frame stop codon 246 nucleotides upstream of this methionine (Fig. 2B). Sequence examination of the region between the stop and methionine codons indicated that there was only one possible non-AUG initiation sequence, AUU, at 207 nucleotides upstream of the methionine codon. An AUU sequence was recently identified in TEF-1 mRNA as a major initiation codon (Xiao et al. 1991). The in vitro translation analysis, however, indicated that protein synthesis started from AUG and not from AUU (data not shown). This AUG was therefore assigned as an initiation codon, although the possibility that the translation starts from AUU in vivo remains to be examined.

The two HES proteins shared $56 \%$ homology with each other in the B-HLH domain. In addition, within the two putative helices of HES- 1 and HES-3 many residues were conserved, including the ones believed to confer HLH domains (Fig. 3B; Benezra et al. 1990). We also found that the sequence WRPW, or a similar one, was conserved in the carboxy-terminal regions of HES-1, HES-3, $h, E(s p l)$, and runt, another Drosophila pair-rule gene product (Fig. 3C) (Kania et al. 1990). Between the B-HLH domain and the carboxy-terminal region, the two HES proteins had a proline-rich portion (amino acid residues 156-247 of HES-1 and 108-167 of HES-3), whereas the $h$ protein had a glutamine-rich part (149-261) (Fig. 3D). Proline-rich and glutamine-rich regions are often found in transcription factors such as CTF/NFl and Spl (Courey and Tjian 1988; Mermod et al. 1989). Another feature involves a serine/threonine-rich region present in HES-1 (248-275) and $h$ (262-298) but not in HES-3.

\section{Spatial and temporal distribution of HES-1 mRNA}

To analyze the tissue distribution and the ontogenetic expression pattern, we performed Northern blot experiments. As shown in Figure 4A, we detected a $1.7-\mathrm{kb}$ HES-1 transcript in the embryos of days 13.5 and 17 (E13.5 and E17; lanes 1, 2), as well as in such adult tissues as the brain (lanes 3-5) and the liver (lane 7). Nerve growth factor (NGF)-treated PC12 cells, which resemble sympathetic neurons (Greene and Tischler 1976), also produced HES-1 mRNA (lane 6). The HES-1 transcript 


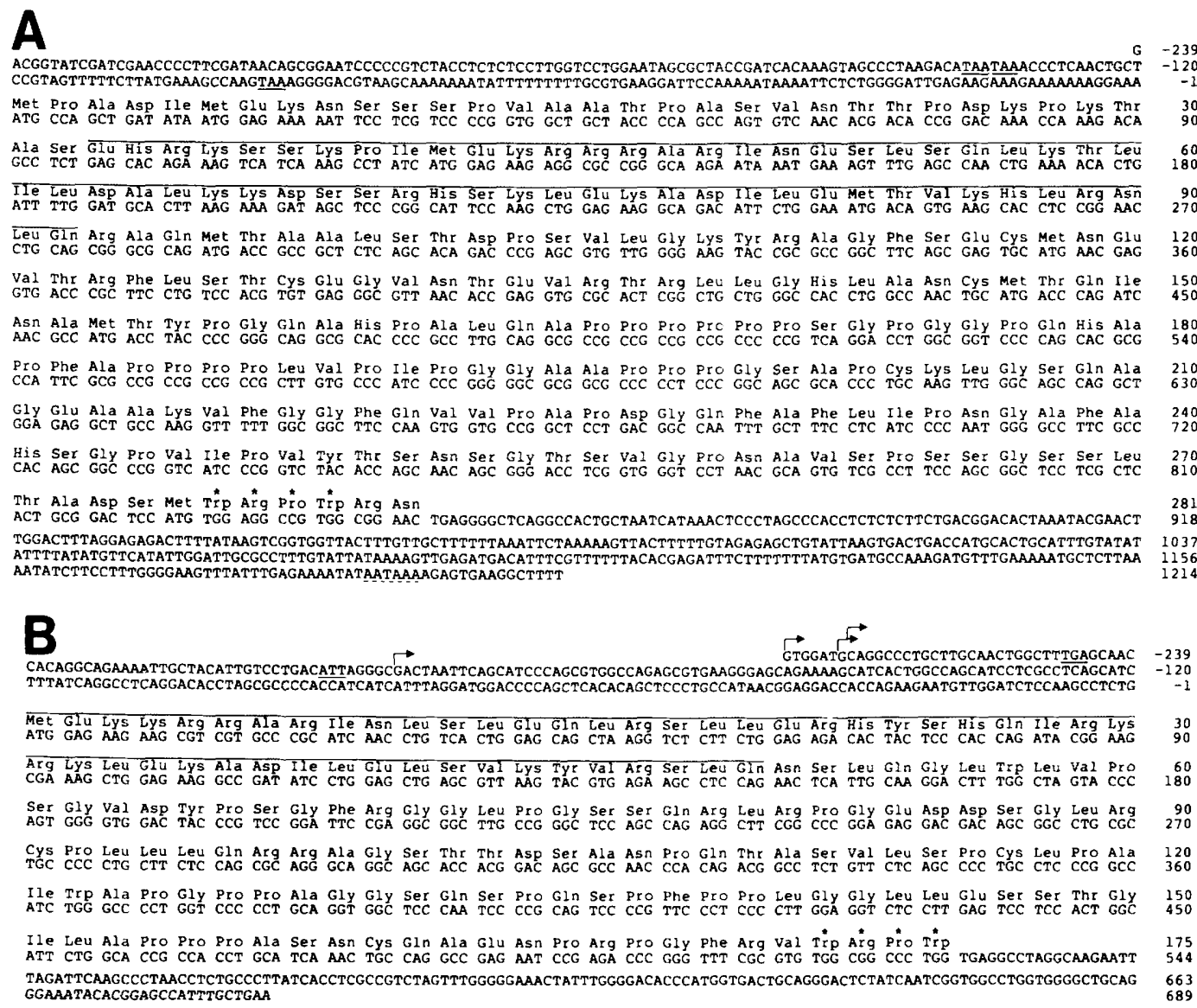

Figure 2. Primary structures of HES-1 and HES-3 clones. $(A)$ The cDNA sequence for rat HES-1 and its deduced amino acid sequence. The deduced amino acid sequence is shown above the nucleotide sequence. The B-HLH region is indicated by a bar above the amino acid sequence. In-frame stop codons at the $5^{\prime}$ flanking region are underlined. The conserved sequence at the carboxyl terminus is indicated with asterisk $(*)$. The possible polyadenylation signal is underscored with a broken line. $(B)$ The cDNA sequence for rat HES-3 and its deduced amino acid sequence. The deduced amino acid sequence is shown above the nucleotide sequence. The B-HLH region is indicated by a bar above the amino acid sequence. In-frame stop and ATT codons at the $5^{\prime}$-flanking region are underlined. The conserved sequence at the carboxyl terminus is indicated with asterisks. $5^{\prime}$-End points of four independent clones are shown by arrows.

was also detected in P19 embryonal carcinoma cells and $10 \mathrm{~T} 1 / 2$ cells (data not shown), which have the potential to differentiate into various tridermic cells and mesodermal cells, respectively (Taylor and Jones 1979; Rudnicki and McBurney 1987), suggesting that HES- 1 is also expressed in such immature cells. To examine the mRNA distribution more precisely, we then conducted RNase protection assays (Fig. 4B). HES-1 mRNA was detected in all of the adult tissues (lanes 3-18) and E18 embryos (lanes 22-31) examined. A high level of HES-1 expression was observed in the lung (lanes 7,26$)$ and gastrointestinal tract (lanes 8,27) of both adults and embryos. The heart, kidney, and muscle also produced the HES- 1 transcript at a high level in the embryo (lanes 28-30) but at a low level in the adult (lanes 10,11; see also Fig. 10D, below). These results demonstrate that the HES-1 expression is widely detected in both adults and embryos but developmentally controlled in a tissue-specific manner.

To determine the cell types expressing HES-1 mRNA, we then carried out in situ hybridization experiments.
Figure 5A shows a typical result with the parasagittal section of rat E14.5. Positive signals were detected in many peripheral epithelial tissues and mesoderm-derived tissues, including the bronchi, gut, nasopharynx, thymus, intervertebral discs, and tongue muscle. These peripheral tissues also gave positive signals in the embryo of day 18 (data not shown; see also Fig. 5E, G). In the central nervous system (CNS) of rat E14.5, a high level of HES-1 mRNA was detected in the cell layers facing the ventricles (arrowheads) and central canal (arrows). As shown in Figure 5B, strong signals were also detected in the cell layers (arrows) facing the ventricles of E18. Such abundant expression of the HES-1 transcript was observed in these layers throughout the CNS on E14.5 and E18. The higher magnification analysis demonstrated that those cells expressing a high amount of HES-1 mRNA were present in the ependymal zone /ventricular zone), where neuroepithelial cells proliferate (Fig. 5D; Fujita 1963; Gilbert 1991|. These neuroepithelial cells are the progenitor cells of both neuroblasts and glioblasts 

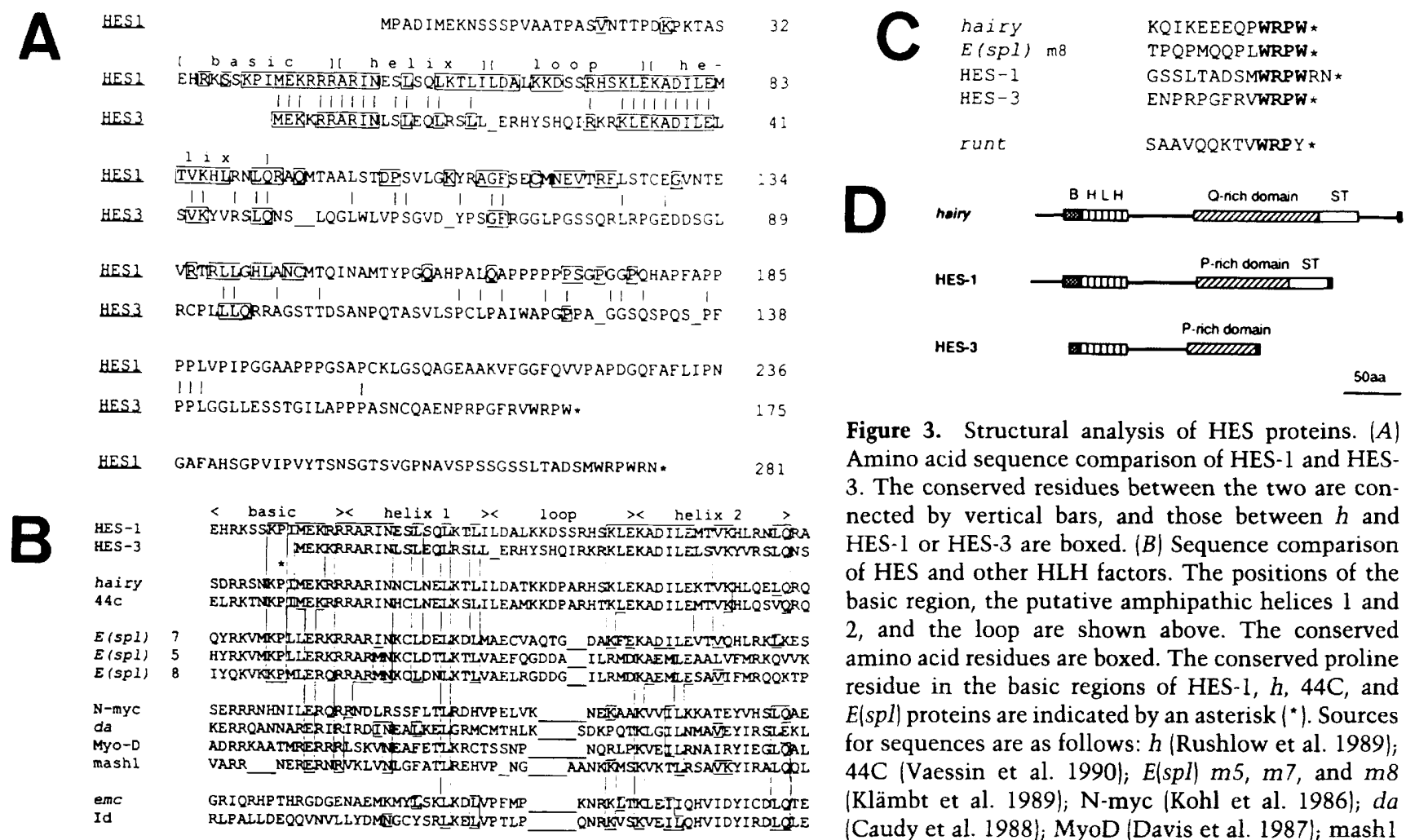

Figure 3. Structural analysis of HES proteins. $(A)$ Amino acid sequence comparison of HES-1 and HES3 . The conserved residues between the two are connected by vertical bars, and those between $h$ and HES- 1 or HES-3 are boxed. (B) Sequence comparison of HES and other HLH factors. The positions of the basic region, the putative amphipathic helices 1 and 2 , and the loop are shown above. The conserved amino acid residues are boxed. The conserved proline residue in the basic regions of HES- $1, h, 44 C$, and $E(s p l)$ proteins are indicated by an asterisk (*). Sources for sequences are as follows: $h$ (Rushlow et al. 1989); 44C (Vaessin et al. 1990); $E(s p I) ~ m 5, m 7$, and $m 8$ (Klämbt et al. 1989); N-myc (Kohl et al. 1986); da (Caudy et al. 1988); MyoD (Davis et al. 1987); mashl (Johnson et al. 1990); emc (Ellis et al. 1990; Garrell and Modolell 1990); and Id (Benezra et al. 1990). (C) Carboxy-terminal sequences are shown. The conserved sequences are indicated by bold letters. $(D)$ Schematic structures of $h$, HES-1, and HES-3 are represented as follows: (Crosshatched boxes), basic regions (B); (vertically striped boxes), helix-loop-helix domains (HLH); (hatched boxes), glutamine (Q)-or proline (P)-rich domains; (open boxes), serine- and threonine-rich regions $(\mathrm{ST})_{;}$(solid boxes), conserved carboxy-terminal sequences shown in $C$.

(Gilbert 1991). In contrast, only low and relatively homogeneous expressions of HES-1 mRNA were detected in the other parts of the embryonal brain such as the mantle layer (Fig. 5D) and the adult brain and spinal cord (data not shown). We also detected high levels of HES-1 mRNA in the epithelial cells of peripheral tissues such as the esophagus and the trachea (Fig. 5E,G). The expression of HES-1 did not seem to correlate merely with cell proliferation. For example, the proliferating neuroblasts in the external granular layer of the neonatal cerebellum produced the transcript only at a background level /data not shown).

In summary, HES-1 mRNA was detected in all tissues examined but was not homogeneous in detail. The expression was enriched in epithelial cells and in such mesoderm-derived cells as embryonal muscle cells. Furthermore, the expression was developmentally controlled in a tissue-specific manner.

\section{Spatial and temporal distribution of HES-3 mRNA}

In contrast to the wide distribution of HES-1 mRNA, a 1.9-kb HES-3 transcript was detected only in the adult brain (Fig. 6A, lanes 3,4) but not in the embryos, NGFtreated $\mathrm{PC} 12$ cells, or the liver (lanes $1,2,6,7)$. In the brain, the cerebellum seemed to be the only place to express HES-3 mRNA; the other brain regions did not produce a detectable amount of the transcript (lanes 4,5 ). This specific expression was analyzed further by RNase protection assays (Fig. 6B). Consistent with the above findings, neither the peripheral tissues nor the spinal cord of adults (lanes 4-12) produced HES-3 mRNA. Furthermore, various brain regions failed to produce HES-3 mRNA (lanes 14,16-18), whereas the cerebellum expressed a significant level of the transcript (lane 15). These results strongly suggest that HES-3 expression occurs only in the cerebellum. None of the nervous or peripheral tissues of embryos (E18) produced HES-3 mRNA (data not shown). Ontogenetic analysis indicated that HES-3 mRNA was undetectable until postnatal day 6 (lane 19). However, the transcript appeared at a low level on the fourteenth day and exhibited a significant increase at the seventh week (lanes 20,21), in marked contrast with HES-1 mRNA, whose level was relatively unchanged during these periods (cf. Fig. 4B, lanes 19-21).

To determine the cell type expressing HES-3 mRNA, we performed in situ hybridization analyses. A high level of HES-3 transcript was detected specifically in the Purkinje cell layer of the adult cerebellum (Fig. 7A). This layer contains Purkinje cells, large arborized neurons receiving $>100,000$ synapses and providing the only known output from the cerebellum. The higher magni- 


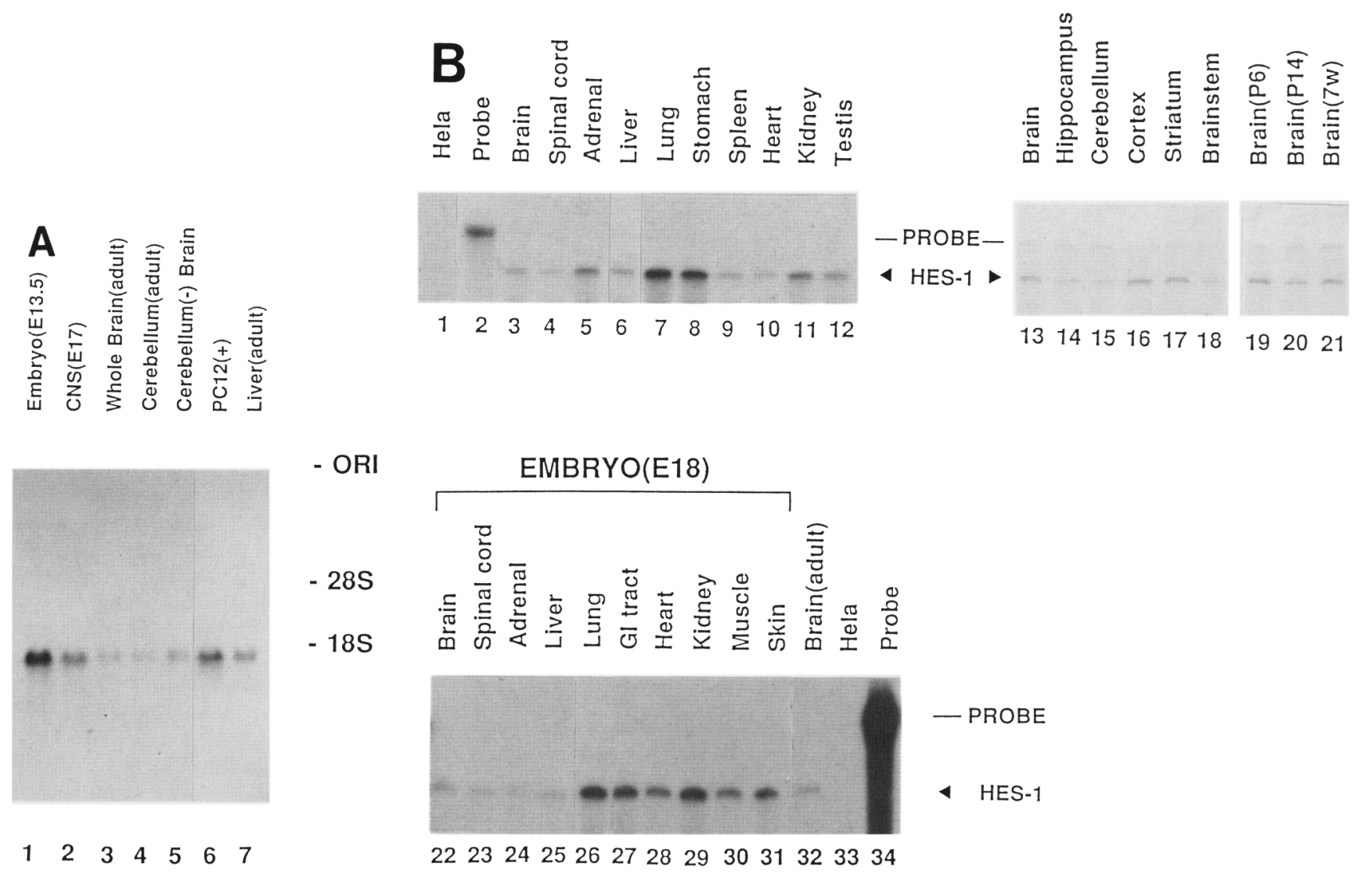

Figure 4. Temporal and spatial distribution of HES-1 mRNA. $(A)$ Northern blot analysis. Five micrograms of poly $(\mathrm{A})^{+}$RNAs was analyzed by using the EcoRI-HincII fragment ( $646 \mathrm{bp}$ ) of pHES-1A as a probe. The probe was hybridized at $42{ }^{\circ} \mathrm{C}$ in $50 \%$ formamide, $5 \times$ SSC, $5 \times$ Denhardt's reagent, $50 \mathrm{~mm}$ sodium phosphate buffer $(\mathrm{pH} 6.8), 0.1 \%$ SDS, and $100 \mu \mathrm{g} / \mathrm{ml}$ of heat-denatured salmon sperm DNA. Under these conditions we observed a single band, and the probe did not cross-hybridize to other species such as HES-3 mRNA. Tissue names are indicated above each lane. (E), Embryonic day; (CNS), central nervous system; [cerebellum $(-\mid$ Brain], adult brain devoid of cerebellum; [PC12 (+ |] NGF-treated PC12 cells. (B) RNase protection analysis. Total RNAs $(30 \mu \mathrm{g})$ of rat adult (lanes 3-18, 32), postnatal (lanes 19-21), or embryonal tissues (lanes 22-31) were hybridized with the antisense cRNA of HES-1. The synthesized probe containing 113 nucleotides derived from the vector and 330 nucleotides of the cRNA (total 443 nucleotides) and the protected band ( 330 nucleotides) are labeled. Human RNA prepared from HeLa cells (lanes 1,33) was used as a negative control. P6, P14, and 7w indicate 6 days, 14 days, and 7 weeks after birth, respectively. (GI tract), Gastrointestinal tract.

fication analysis clearly demonstrated that HES-3 gene was predominantly transcribed in Purkinje cells (Fig. 7C). No positive signals were detected in any other parts of the brain, the retina, or the embryo sections of E14.5 and E18 (data not shown). Thus, HES-3 gave the striking observation of a neuron type-specific transcription factor in the mammalian CNS. Consistent with RNase protection assays, no apparent signals were detected until postnatal day 5 , but significant signals were detected in maturating Purkinje cells on postnatal day 11 /data not shown), thus suggesting that the appearance of HES-3 mRNA coincides with the terminal differentiation of these cells (Ito 1984).

\section{DNA-binding analysis of HES-1}

To characterize the functions of the HES factors, we first assessed DNA-binding activity. The HES-1 protein was expressed in Escherichia coli and subjected to DNase I footprinting analysis. Although $\mathrm{HLH}$ factors such as MyoD have been shown to recognize the consensus sequence CANNTG (called the E box; Blackwell and Weintraub 1990|, the introduction of a proline into the basic region of MyoD results in the loss of DNA-binding activity (Davis et al. 1990). However, a recent study shows that $E(s p l)$ proteins, each of which contains a proline in its basic region (see Fig. 3B), bind to a different sequence, CACNAG (called the $\mathrm{N}$ box), present in a cluster in the $5^{\prime}$ regulatory regions of $E(s p l)$ genes themselves (Klämbt et al. 1989; Tietze et al. 1992; N. Oellers and E. Knust, pers. comm.). Therefore, we first tested whether HES-1, which also has a proline in the basic region, binds to the $\mathrm{N}$-box sequence. As shown in Figure 8A, HES-1 clearly bound to the N-box regions (lane 3). Both CACAAG and CACGAG sequences were well protected by HES-1. The mutation analysis showed that the sequence CAC/A/G)AG was recognized most efficiently by HES- 
A
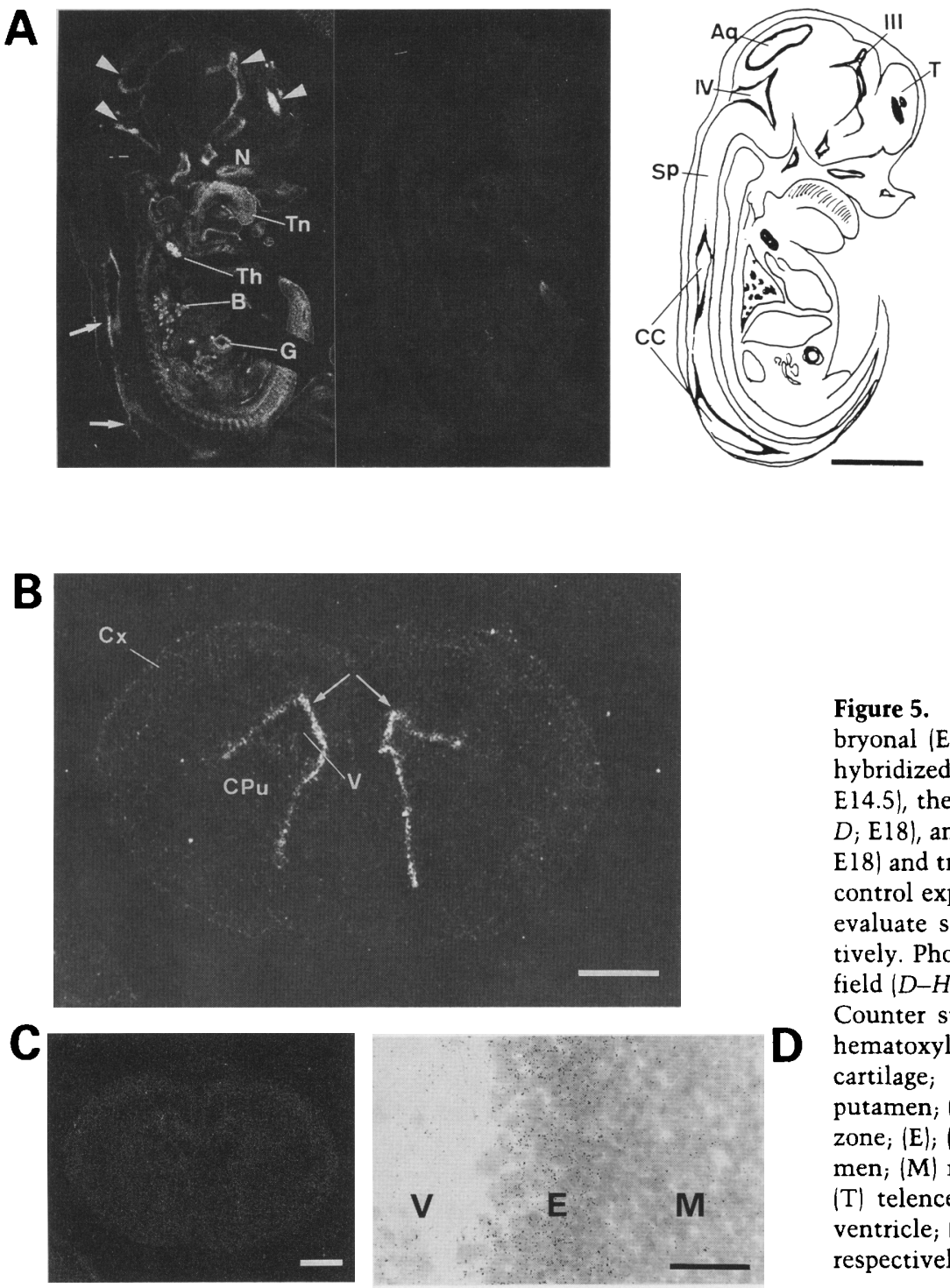

1(Fig. 8B, lane 1). The mutation in the first, second, third, or sixth nucleotide of the CACNAG sequence totally abolished HES-1 binding (lanes 2,3,4, and 8, respectively). The fourth position preferred $A$ and $G$ to $T$ and $C$ for HES-1 binding (lanes 5, 6). When the fifth nucleotide, A, was changed to $\mathrm{T}$ (thus conforming to the $\mathrm{E}$ box), a weak band (approximately one-eighth of the wild type) was observed (lane 7). Consistent with this result, only when an excess amount of HES-1 protein was used in the DNase I footprinting analysis could a slight difference in intensities be observed in several bands of the E-box regions (Fig. 8C, lane 2). We also tested several other $\mathrm{E}$ boxes such as the one in the muscle creatine kinase (MCK) enhancer but failed to detect effective HES-1 binding (see also Fig. 10B, lane 6, below). These results indicated that HES-1 bound more preferentially to the $\mathrm{N}$ box than to the E box. On the other hand, E47, an HLH
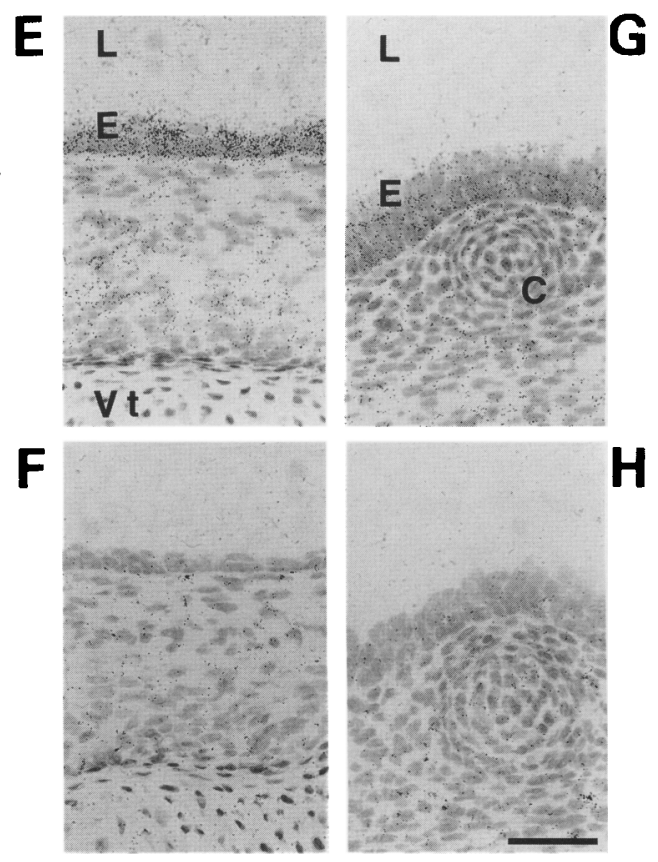

Figure 5. In situ hybridization analysis of HES-1 with embryonal (E14.5 and E 18) sections. The HES-1 probe was hybridized to the parasagittal section of a rat embryo $\langle A$; E14.5), the coronal sections of the rat embryonal brain (B$D ; E 18)$, and the sections of the embryonal esophagus $(E, F$; E18) and trachea $(G, H$; E18). A (middle), $C, F$, and $H$ show control experiments carried out with excess cold cRNA to evaluate specific signals in $A$ (left), $B, E$, and $G$, respectively. Photos were taken in a dark field $(A-C)$ or a bright field $(D-H)$. Bars, $2 \mathrm{~mm}(A), 1 \mathrm{~mm}(B, C)$ or $50 \mu \mathrm{m}(D-H)$. Counter stains were carried out with cresylviolet $(D)$ or hematoxylin-eosin (E-H). (Aq) Aqueduct; (B) bronchi; (C) cartilage; $(\mathrm{CC})$ central canal; $(\mathrm{CPu})$ primordial caudateputamen; $(C x)$ primordial cortex; $(E)$; (panel $D)$, ependymal zone; (E); (panels $E$ and $G$ ), epithelial cells; (G) gut; (L) lumen; (M) mantle zone; (N) nasopharynx; (Sp) spinal cord; (T) telencephalon; (Th) thymus; (Tn) tongue; (V) lateral ventricle; (Vt) vertebra; (III, IV) third and fourth ventricles, respectively.

factor without a proline in the basic region, bound efficiently to the $\mathrm{E}$ box, but not to the $\mathrm{N}$ box (Fig. 8B, lanes $10,16)$.

Because the mutant MyoD containing a proline in the basic region inhibits the DNA-binding ability of other HLH factors, we then analyzed whether HES-1 attenuates the DNA-binding activity of other HLH factors. E47/E12 (Pan 1/Pan 2), two species produced from the E2A gene by alternative splicing, are well-characterized HLH factors. They are ubiquitously expressed in all cell types and bind to E-box sequences such as the $\mathrm{KE} 2$ site and the insulin enhancer (Murre et al. 1989; Nelson et al. 1990). As shown in Figure 8C, E. coli-expressed E47 clearly protected the $\mathrm{kE} 2$ sequence in the DNase I footprinting analysis (lane 4). The addition of an equimolar amount of HES-1, however, resulted in complete inhibition of the DNA-binding activity of E47. We then ana- 


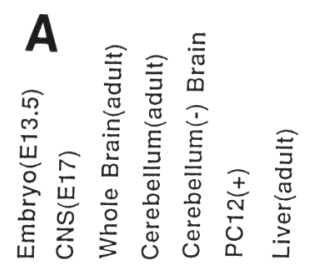

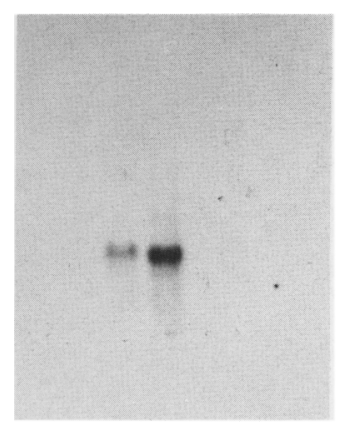

$\begin{array}{lllllll}1 & 2 & 3 & 4 & 5 & 6 & 7\end{array}$
- ORI

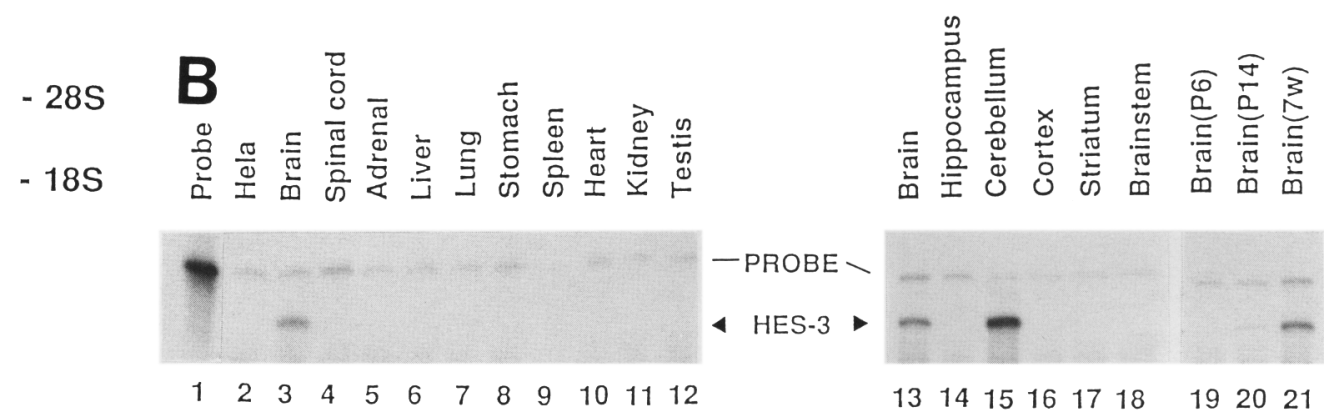

Figure 6. Temporal and spatial distribution of HES-3 mRNA. $(A)$ Northern blot analysis. Five micrograms of poly $(A)^{+}$RNAs was analyzed by using the EcoRI-SmaI fragment $(713 \mathrm{bp}$ ) of pHES-3A as a probe. The hybridization conditions were the same as that in HES-1 experiment. Tissue names are indicated above each lane, as in Fig. 4. (B) RNase protection analysis. Total RNAs (30 $\mu$ g) of rat adult (lanes 3-18) or postnatal tissues (lanes 19-21) were hybridized with the antisense cRNA of HES-3. The synthesized probe containing 118 nucleotides derived from the vector and 312 nucleotides of the cRNA (total 430 nucleotides) and the protected band (312 nucleotides) are labeled. Human RNA prepared from HeLa cells (lane 2) was used as a negative control.

lyzed whether HES-1 affects the DNA-binding activity of a different type of transcription factor. ATF-2, which has a leucine zipper motif but not an HLH domain, binds to the cAMP response element (CRE) (lane 7). The addition of an equimolar amount of HES-1 did not alter the DNAbinding ability of ATF-2 (lane 8). Furthermore, even a 10-fold molar excess of HES-1 caused no change in the ATF-2 activity (lane 9). Therefore, these data suggest that HES- 1 specifically inhibits the DNA-binding activity of certain HLH factors.

We also attempted to examine HES-3 expression in $E$. coli to characterize its activity. However, for unknown reasons we failed to express HES-3 protein in E. coli.

\section{Transcriptional analyses of HES-1 and HES-3}

To characterize the transcriptional activities of the HES factors, we performed DNA-mediated gene transfer experiments using NIH-3T3 cells. HES-1, HES-3, and E47 cDNAs were subcloned into the eukaryotic expression vector containing the cytomegalovirus (CMV) enhancer and promoter. Reporter plasmids were comprised of the
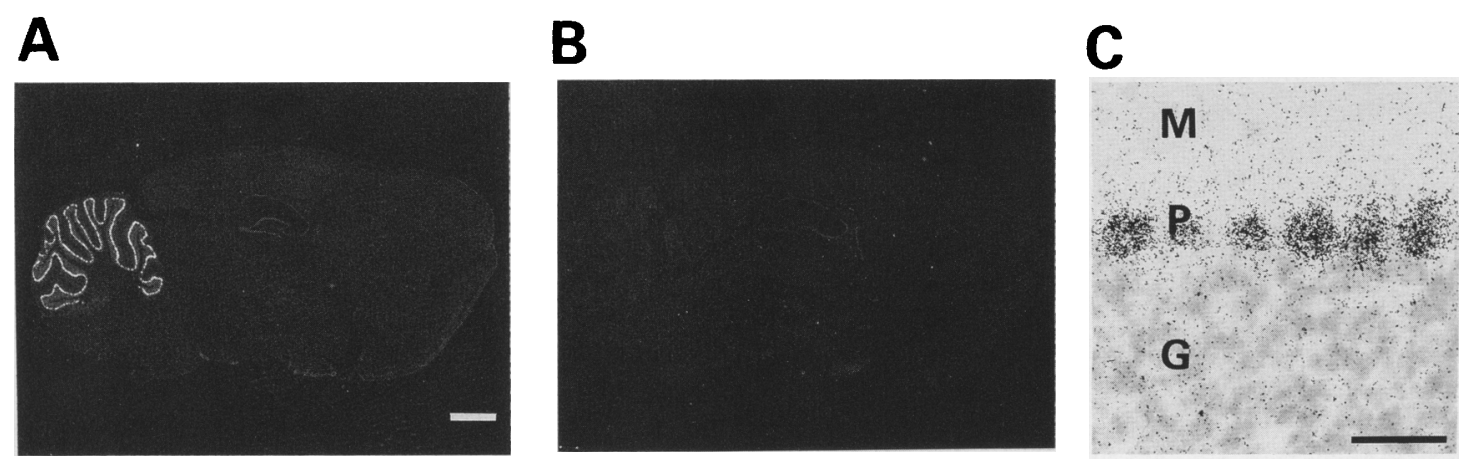

Figure 7. In situ hybridization analysis of HES-3 with adult brain. HES-3 probe was hybridized to the sagittal sections of rat adult brain $(A, B)$ and cerebellum $\{C \mid .(B)$ Control experiment carried out with excess cold cRNA to evaluate specific signals in $A$. Photos were taken in a dark field $(A, B)$ or a bright field $(C)$. Bar, $2 \mathrm{~mm}(A, B)$ or $50 \mu \mathrm{m}(C)$. Counter stain was carried out with cresylviolet (C). (M) Molecular layer; (P) Purkinje cells; (G) granular layer. 


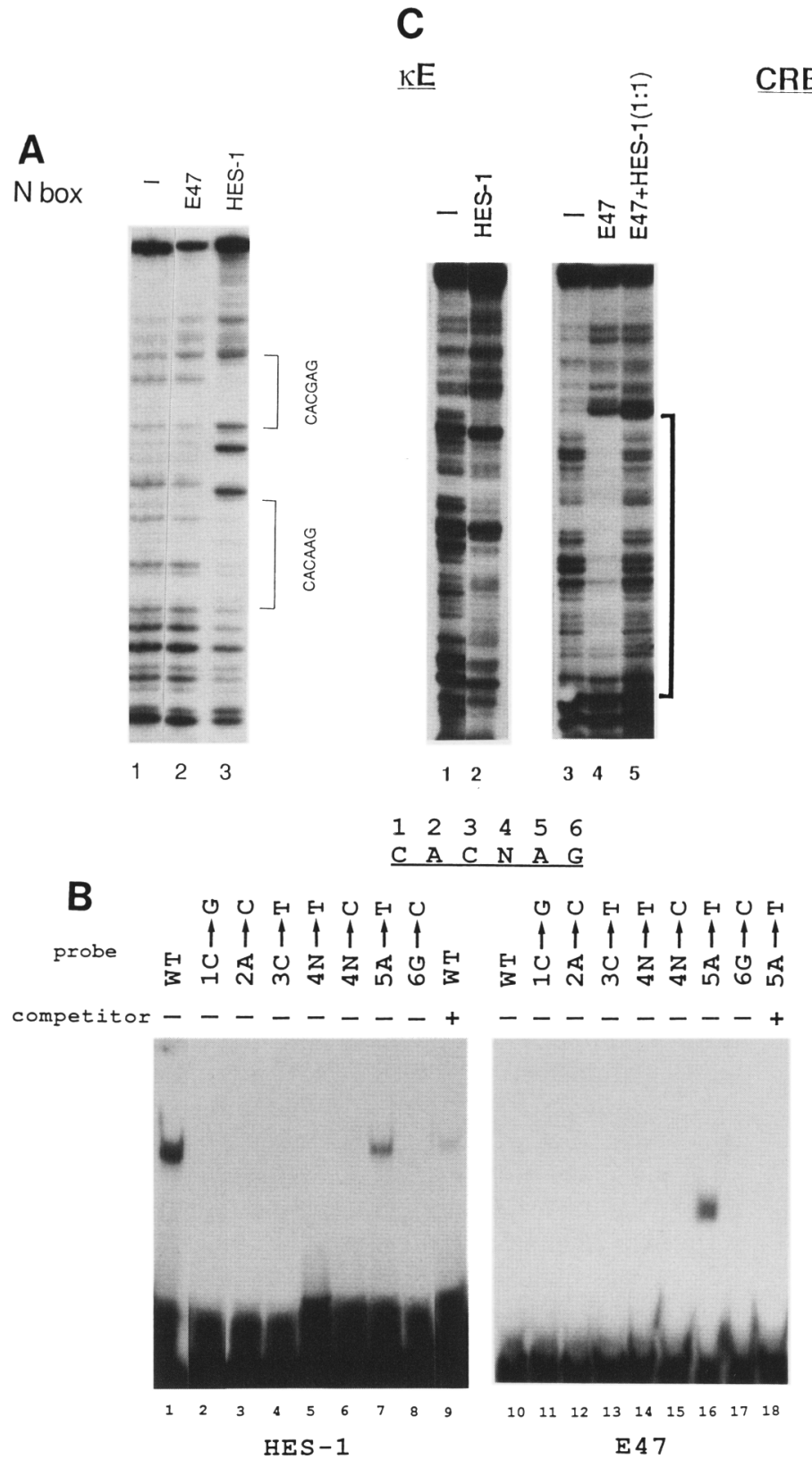

chloramphenicol acetyltransferase (CAT) gene under the control of the $\beta$-actin promoter linked to either six repeats of the N boxes (pN6- $\beta \mathrm{A}-\mathrm{CAT}$ ) or seven repeats of the $E$ boxes (pкE7- $\beta A-C A T)$.

HES-1 significantly repressed CAT expression from the promoter containing the $\mathrm{N}$ boxes, whereas HES-3 and $\mathrm{E} 47$ did not affect CAT expression from the same promoter (Fig. 9A, lanes 1-4). HES-1 did not repress expression from the promoter containing the mutated $\mathrm{N}$ boxes (CATNAG) that lost affinity for HES-1 (Fig. 9A, lanes 5,6$)$. These results thus indicated that HES-1 acted as a transcriptional repressor by binding to the $\mathrm{N}$ box in this assay.

E47, on the other hand, activated CAT expression from the promoter containing the $\mathrm{E}$ boxes when compared with the basal level exhibited by the CAT plasmid alone (Fig. 9B lanes 1,2). However, when either HES-1 or HES-3 expression vector was cotransfected with the E47 plasmid, E47-induced CAT expression was totally abolished (E47 + HES-1 and E47 + HES-3). In the case of E47 + HES-1, CAT activity was even lower than the basal level, probably because HES-1 effectively antagonized the endogenous E12/E47 or equivalent HLH activators. HES-1, as well as HES-3 plasmids alone, also showed less CAT activity than the basal levels, probably for the same reason as noted above. These HLH factors had no effects on the control $\beta$-actin promoter (data not shown|. The results thus demonstrate that both HES-1 and HES- 3 negatively regulate transcription.

HES-1 represses the functions of MyoD and MASH1

The above findings that HES genes encode transcription 
Figure 9. Negative transcriptional regulation by HES factors. $(A)$ Ten micrograms of the CAT reporter plasmid containing six repeats of wild-type $N$ boxes (CACNAG) (1-4) or mutated $N$ boxes (CATNAG) (lanes 5, 6) was cotransfected into NIH-3T3 cells with $10 \mu \mathrm{g}$ of the control vector pSV-CMV alone $(-)$, the HES expression plasmid (HES-1 and HES-3), or the E47 expression plasmid (E47). (B) CAT analysis by cotransfection assays. Two micrograms of the CAT reporter plasmid containing seven $\mathrm{\kappa E2}$ sites (shown at left) was cotransfected into NIH-3T3 cells with $16 \mu \mathrm{g}$ of the control vector pSV-CMV alone $(-1,8 \mu \mathrm{g}$ of the HES plasmid (HES- 1 and HES-3), $8 \mu \mathrm{g}$ of the E47 plasmid (E47), or $8 \mu \mathrm{g}$ each of the HES and E47 expression plasmid (E47 + HES-1 and E47 + HES-3), as depicted. Total amounts of DNA were adjusted with the control vector pSVCMV. Cells were harvested $48 \mathrm{hr}$ later, and CAT activities were measured. Each value of relative CAT activities is the average of and the standard deviation for at least four independent experiments that were done in duplicate.

factors with developmentally controlled expression patterns prompted us to investigate their functions further in tissue differentiation. RNA distribution analyses suggested the coexistence of HES-1 with at least two other HLH factors involved in tissue differentiation, MyoD and MASH1. MyoD is expressed at a high level in embryonal muscle cells (Buckingham 1992), MASH1 is transcribed in subsets of neuroepithelial cells and neural crest-derived PC12 cells (Johnson et al. 1990; Lo et al. 1991), and HES-1 is also expressed in those cells (Figs. 4 and 5). Therefore, we examined the effects of HES- 1 on these factors.

As shown in Figure 10A, both MyoD and MASHl significantly activated transcription from the promoter containing the MCK enhancer (lanes 4,8). Previous reports indicated that the MyoD/E47(E12) and MASHl/ E47(E12) complexes, rather than the MyoD and MASH1 homo-oligomers, are responsible for these trans-activations (Weintraub et al. 1991; Johnson et al. 1992). In agreement with these reports, the addition of exogenous E47 further enhanced the trans-activations by MyoD and MASHl (lanes 6,10). However, the coexpression of HES-1 with these oligomers resulted in complete inhibition of transcriptional activation (lanes $5,7,9,11$ ). Neither HES-1 nor E47 alone affected the basal level of transcription (lanes 2,3 ). These results clearly demonstrated that HES- 1 acts as a negative regulator of MyoD and MASH1.

Gel mobility-shift assays showed that MyoD/E47 and MASH1/E47 mixtures bound strongly to the MCK E-box sequence (Fig. 10B, lanes 7,11). However, the addition of HES-1 led to the inhibition of the DNA-binding activities of the MyoD/E47 and MASH1/E47 complexes (lanes $8,12)$. This negative regulation of HES-1 is probably the result of the deprivation of $\mathrm{E} 47$ from the complexes because HES-1 did not inhibit the DNA-binding activity of the MyoD homo-oligomer (lanes 2,3) but did inhibit that of E47 effectively (see Fig. 8C). A weak band remained when HES- 1 was added to the MyoD/E47 complex (lane 8). This may be the result of either weak binding of the MyoD homo-oligomer or binding of the remnant MyoD/ E47 complex. MASH1 alone failed to bind to the MCK E box (lane 10), as reported previously (Johnson et al. 1992).

We then examined the effect of HES-1 on the myogenic conversion of $10 \mathrm{~T} 1 / 2$ cells induced by MyoD. As shown in Figure 10C (top), MyoD effectively converted the cells into cells with muscle phenotypes (also see Table 1). Cotransfection of HES-1 expression plasmid, however, significantly decreased MyoD-induced myogenic conversion (Fig. 10C, bottom; Table 1), agreeing well with the above findings that HES- 1 is a negative regulator of MyoD. Furthermore, the expression of HES-1 transcript was regulated in the course of myogenesis. HES-1 mRNA was expressed at a high level in the embryonal muscle while it was transcribed only at a low level in the adult muscle (Fig. 10D, lanes 1,2). These results suggest that HES-1 may act as a negative regulator of myogenesis in vivo.

\section{Discussion}

\section{Structure and distribution of the HES family}

In this study we have described the molecular cloning and characterization of the HES family, novel mammalian HLH factors. Both HES-1 and HES-3 have significant sequence homology in the B-HLH domain to Drosophila $h$ and $E(s p l)$ proteins, as well as the conserved carboxyterminal sequence WRPW. These results suggest that the mammalian HES and Drosophila $h$ and $E(s p l)$ genes originated from the same or closely related ancestral genes.

HES- 1 and HES-3 genes show contrasting expression patterns: wide distribution in the former and Purkinje cell-specific expression in the latter. In the embryonal 

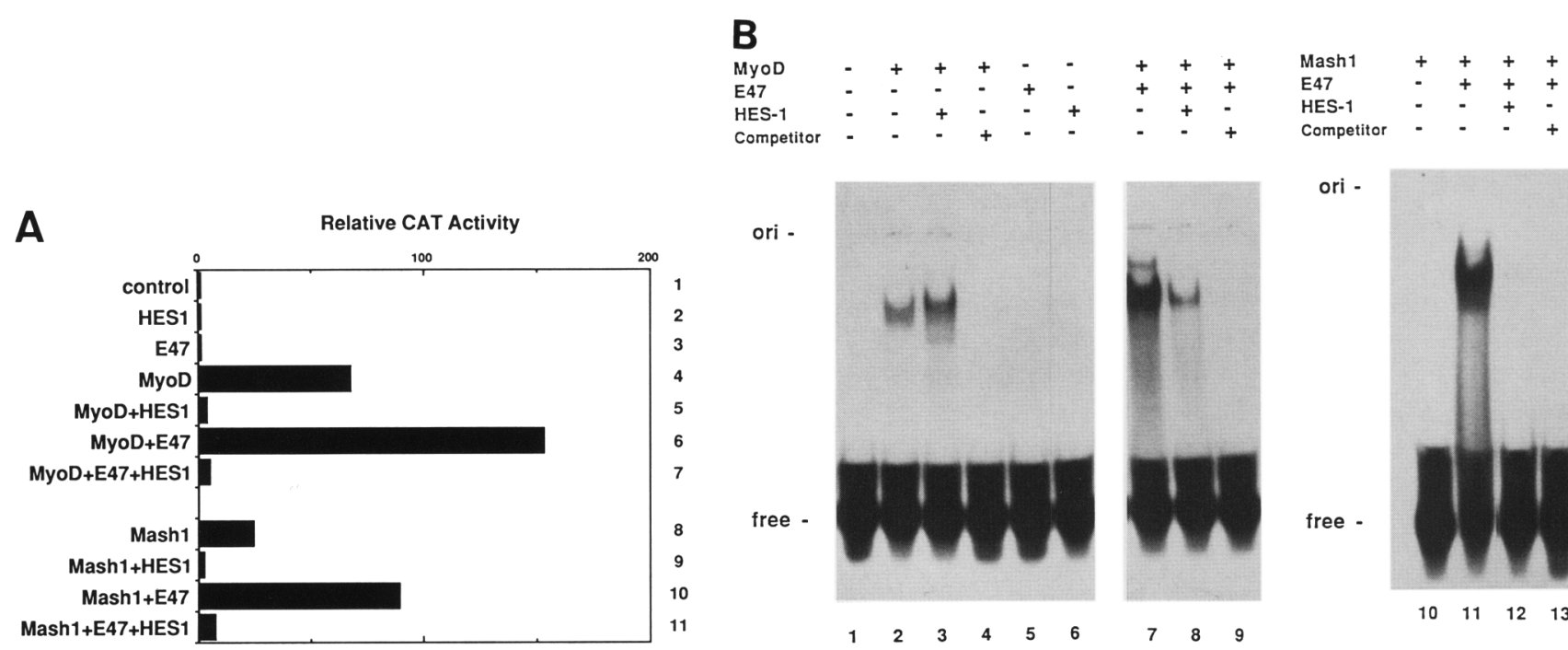

A

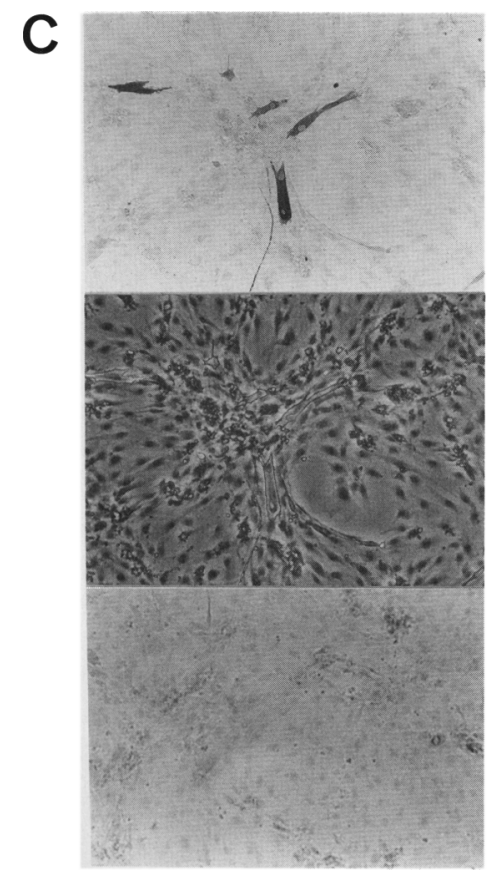

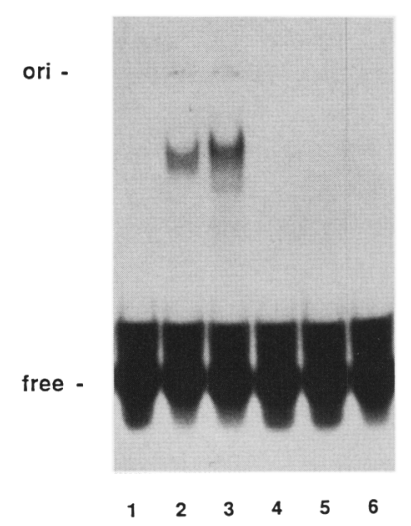

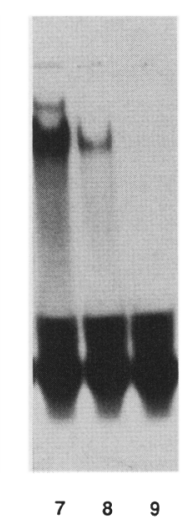

ori -

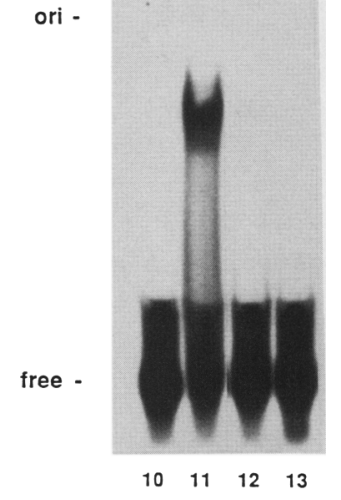

Figure 10. Repression of the functions of MyoD and MASHl by HES-1. (A) CAT analysis. Two micrograms of the CAT reporter plasmid containing the MCK enhancer were cotransfected into $10 \mathrm{~T} 1 / 2$ cells $(9-\mathrm{cm}$ plate) with either the control vector alone (lane 1), $12 \mu \mathrm{g}$ of HES-1 expression plasmid (lane 2), $4 \mu \mathrm{g}$ of the E47 expression plasmid (lane 3), $4 \mu \mathrm{g}$ of the MyoD expression vector (lane 4), $4 \mu \mathrm{g}$ of the MASHl expression plasmid (lane 8), or a combination of these plasmids (lanes 5-7, 9-11). (B) Gel mobility-shift assays were performed with ${ }^{32}$ P-labeled synthetic oligonucleotide containing the E-box motif in the MCK enhancer $(0.2 \mathrm{ng})$. The amounts of $E$. coli-expressed proteins used were as follows: MyoD, $20 \mathrm{ng}$ in lanes 2-4 and $4 \mathrm{ng}$ in lanes 7-9; E47, $2 \mathrm{ng}$; HES-1, $200 \mathrm{ng}$ in lane 3 and $40 \mathrm{ng}$ in lanes 6, 8, and 12; and MASH1, $100 \mathrm{ng}$ in lane 10; and $10 \mathrm{ng}$ in lanes 11-13. Competition experiments were performed with $200 \mathrm{ng}$ of cold oligonucleotide (lanes 4, 9, 13). The apparent enhancement of MyoD binding by the addition of HES-1 (lane 3) was not reproducible; thus, it seemed to reflect some experimental variation. $(C \mid$ Myogenic conversion induced by MyoD and its inhibition by HES-1. (Top) $10 \mathrm{~T} 1 / 2$ cells converted by forced expression of MyoD were immunostained with anti-myoglobin antisera. The $A B C$ peroxidase method (Vectastain) was used. (Middle) A phase-contrast photomicrograph of the same visual field as that in the top. (Bottom) 10T1/2 cells transfected transiently with the expression vectors of MyoD and HES-1 (1:3; see Table 1)

were immunostained with anti-myoglobin antisera. Positive cells were very rare. $(D)$ Northern blot analysis with HES-1 probe. Total RNAs $(20 \mu \mathrm{g}$ ) from the rat muscle of E18 (lanes 1,3) or adult (lanes 2, 4) were analyzed. Lanes 3 and 4 show the ethidium bromide staining of the agarose gel corresponding to lanes 1 and 2 , respectively.

CNS, HES- 1 is expressed at a high level by the neural progenitor cells present in the ependymal zone, but it decreases rapidly as neural differentiation proceeds. In the Drosophila eye, $h$ is once expressed in undifferentiated cells as the morphogenetic furrow approaches, but it is lost before neural differentiation is manifest (Carroll and White 1989). Thus, the time course of HES-1 expression regarding neural differentiation is somewhat similar to that of $h$. However, while the Drosophila $h$ gene is not expressed by committed neural precursor cells or neurons, HES-1 mRNA is still present in those cells, although only at a low level. Thus, the expression pattern of HES- 1 seems different from that of $h$ in the differentiated nervous system.

In peripheral tissues, HES- 1 is preferentially transcribed in the epithelial cells of the respiratory and gastrointestinal tracts and in embryonal mesoderm-derived tissues such as the muscle. During late embryogenesis, Drosophila $h$ is transiently expressed in various regions including the tracheal pit, some parts of the gut, and the mesoderm (Carroll et al. 1988; Carroll and Whyte 1989; Hooper et al. 1989/. Thus, the expression pattern of HES-1 in the peripheral tissues seems, at least in part, similar to that of the Drosophila h gene, although simple 
Sasai et al.

Table 1. Inhibition of MyOD-induced myogenic conversion by HES-1

\begin{tabular}{lccc}
\hline Plasmid $^{\mathrm{a}}$ & Myoglobin $(+)^{\mathrm{b}}$ & $\beta$-gal $(+)^{\mathrm{b}}$ & $\begin{array}{l}\text { Myoglobin }(+\mid) \\
\beta \text {-gal }(+\mid \%)\end{array}$ \\
\hline 1. Control & 0 & 2658 & 0 \\
2. HES-1 & 0 & 2470 & 0 \\
3. MyoD & 3636 & $2501^{\mathrm{c}}$ & 145 \\
4. MyoD + HES-1 $(1: 1)$ & 528 & 2803 & 18 \\
5. MyoD + HES-1 $(1: 3)$ & 92 & $2915^{\mathrm{c}}$ & 3 \\
\hline
\end{tabular}

${ }^{a} 10 \mathrm{~T} 1 / 2$ cells on 5 -cm $\phi$ dishes were transfected with the MyoD expression vector $(1 \mu \mathrm{g}$ in 3-5) and/or the HES-1 expression vector 3 $\mu \mathrm{g}$ in 2 and $5 ; 1 \mu \mathrm{g}$ in 4). pCDM8- $\beta$-gal $(0.5 \mu \mathrm{g})$ was cotransfected onto each plate to evaluate transfection efficiency. The amount of plasmid DNA was adjusted to $5 \mu \mathrm{g}$ with the control expression vector.

${ }^{\mathrm{b}}$ The numbers of positive cells that were stained with anti-myoglobin immunoreactivity or $\beta$-galactosidase activity were counted in 5 -cm $\phi$ dishes. In the case of $\beta$-galactosidase staining, when $\beta$-gal $|+|$ cells were found in doublets owing to proliferation, they were counted as one transfected cell to avoid overestimation of transfection efficiency.

${ }^{c}$ The majority of $\beta$-gal $|+|$ cells transfected with the MyoD plasmid was longer and larger than background 10T1/2 cells and did not seem to proliferate. They often had multiple nuclei and overlay the background cells. These characteristics were the same as those found in myoglobin $|+|$ cells transfected with MyoD plasmid (Fig. 10C). In contrast, the $\beta$-gal $|+|$ cells transfected with MyoD + HES- 1 $(1: 3)$ or control plasmid were morphologically indistinguishable from background cells and many of them were proliferating.

comparison is difficult because the anatomical structures and developmental processes are so different between invertebrates and vertebrates.

In contrast to HES-1, HES-3 substantially diverges from $h$ in its structure as well as in its expression pattern. HES-3 is not expressed in any of the embryonal tissues tested but appears in cerebellar Purkinje cells between postnatal days 6 and 11. In the rat, Purkinje cells originate between days E14 and E17 and then migrate and align in a monolayer during the first 4 days after birth. The postnatal growth and synaptic maturation of Purkinje cells continue during the first month (Ito 1984). Thus, the HES-3 expression pattern, with its lack of expression in the embryo and its postnatal sharp increase, suggests that HES-3 may be involved in the maturation and functional maintenance of Purkinje cells rather than their fate determination.

\section{Transcriptional repression by HES factors}

In transient cotransfection assays, we have shown that both HES-1 and HES-3 are negative regulators of transcription. HES-1 represses transcription by acting on two types of sequences, the $\mathrm{E}$ box and the $\mathrm{N}$ box, whereas HES- 3 seems to act only on the $E$ box.

HES-3 has no effects by itself on either the $N$ box or the $E$ box, and this inability is probably the result of the deletion of the amino-terminal half of the basic region. In this sense, HES-3 is similar to Id and HLH462, both of which lack the basic region. These two HLH negative regulators do not bind to the DNA template by themselves but inhibit other activators from binding by forming nonfunctional heterodimers (Benezra et al. 1990; Christy et al. 1991). Thus, because HES-3 has an intact $\mathrm{HLH}$ domain, transcriptional repression by HES-3 is probably mediated through formation of a nonfunctional heterodimer with HLH activators.

In contrast, because HES- 1 binds directly to the $\mathrm{N}$ box, its repressor activity seems unique compared with that of Id, HLH462, and HES-3. The mechanism of how HES-1 represses transcription through the $\mathrm{N}$ box is an intriguing problem. Competition for the $\mathrm{N}$ box between HES- 1 and $\mathrm{N}$ box-binding activators is probably unlikely because $\mathrm{N}$ box-dependent transcriptional activation was not detected in NIH-3T3 cells (Fig. 9A, cf. lanes 1 and 5). Thus, HES-1 may negatively influence other factors that may be essential for transcription. In this regard, a region rich in prolines, a feature often observed in the domains involved in protein-protein interaction (Mermod et al. 1989/, may be interesting. Further studies should be done to address how HES-1 binding to the $\mathrm{N}$ box leads to transcriptional repression and which mammalian genes are regulated by HES-1 through the $\mathrm{N}$ box in vivo.

The mechanism of how HES-1 represses transcription through the $\mathrm{E}$ box is also an interesting question. Although HES-1 does not bind to the $\mathrm{E}$ box with a high affinity, it strongly antagonizes the function of $\mathrm{HLH}$ activators such as E47. Thus, like HES-3, Id, and HLH462, it is likely that nonfunctional heterodimer formation is responsible for negative regulation by HES-1, although it is possible that weak but direct interaction of HES-1 with the $\mathrm{E}$ box may also contribute to this negative regulation. These results indicate that HES-1 could repress transcription by two different mechanisms, depending on the sequences: repression by direct interaction with the $\mathrm{N}$ box and inhibition of other HLH activators from binding to the $\mathrm{E}$ box.

\section{HES-1 negatively regulates the functions of MyoD and MASH1}

HES-1 negatively regulates the functions of $M y o D$ and MASHl by inhibiting the MyoD/E47(E12) and MASH1/ E47(E12) complexes from binding to their target sequences. Our DNA-binding analysis shows that HES-1 does not inhibit the DNA-binding activity of the MyoD 
homodimer but almost completely inhibits that of E47. Thus, this strong interaction of HES-1 with E47 may lead to deprivation of the latter from the MyoD/E47 and MASHl/E47 complexes, resulting in the repression of MyoD and MASH1. However, other possibilities should also be considered. For example, excess HES-1 could form more multimeric oligomers such as the MyoD/ E47/HES-1 or MASH1/E47/HES-1 complexes. Weak interaction of HES-1 with the E box (Fig. $8 \mathrm{~B}$ ) could also lead to interference of the DNA binding of $\mathrm{MyoD}$ and MASHl.

HES-1 expression is developmentally controlled during myogenesis: Expression is at a high level in the embryonal muscle but at a low level in the adult muscle (Figs. 5A and 10D). Furthermore, it represses the MyoDinduced myogenesis of $10 \mathrm{~T} 1 / 2$ cells. Thus, it seems reasonable to hypothesize that HES-1 negatively regulates muscle differentiation in vivo. In this regard, the function of HES-1 is again similar to that of Id. However, the quantitative regulations of these two factors seem different in the course of muscle differentiation. When $10 \mathrm{~T} 1 / 2$ cells are treated with serum-free medium /differentiation medium/, Id mRNA decreases dramatically (Weintraub et al. 1991), whereas HES-1 mRNA increases by severalfold (data not shown). The latter then decreases in late myogenesis (Fig. 10D). These results suggest that HES-1 and Id could take part in the regulation of muscle differentiation at different stages. However, we cannot exclude the possibility that HES- 1 is not directly relevant to muscle differentiation but is involved in other functions in the developing muscle. Thus, whether the effects of HES-1 observed in the cell culture system reflect the in vivo situation should await further studies.

HES-1 also negatively regulates the function of MASH1, a mammalian homolog of Drosophila AS-C. In Drosophila, genetic analyses have shown that $h$ has antagonizing activities against the proneural gene $a c$. Thus, our findings show interesting functional conservation between Drosophila $h / a c$ and mammalian HES-1/ MASH1. However, little is yet known about the in vivo function of MASH1, including its target genes, although the temporal and spatial expression pattern suggests the possible involvement of MASH1 in neural differentiation (Lo et al. 1991). Therefore, in vivo function of HES-1 in relation to that of MASH1 awaits further analyses.

Our studies now provide the basis to investigate the intriguing questions discussed above, and further analysis of the HES genes will help in the understanding of the roles of HLH proteins in mammalian development.

\section{Materials and methods}

\section{RNA isolation}

Various tissues were obtained from 7-week-old Sprague-Dawley male rats and rat embryos of the indicated embryonic days. Poly $(\mathrm{A})^{+}$RNA was prepared from total RNA by using oligo(dT) latex (Roche). The yield of poly $(\mathrm{A})^{+}$RNA/total RNA was 3.2$5.7 \%$ depending on the type of tissues.

\section{$P C R$ experiments}

After reverse transcription with oligo(dT) priming of poly $(\mathrm{A})^{+}$ RNA from whole embryo of day 17 or adult brain, the cDNA was submitted to $30-40$ cycles of PCR under standard conditions (Lee et al. 1988; Saiki et al. 1988), except that the annealing temperature was lowered to $45^{\circ} \mathrm{C}$ during the first five cycles. The fully degenerate primers corresponding to the following sequences were synthesized: RRAR(I/M)N and $\mathrm{KAD}(\mathrm{I} / \mathrm{M}) \mathrm{LE}$ for the $5^{\prime}$ and $3^{\prime}$ primers, respectively. The third codon positions of fourfold degeneracy were substituted by inosine. BamHI and EcoRI sites were introduced at the $5^{\prime}$ end of the $5^{\prime}$ and $3^{\prime}$ primers, respectively (the resulting primers were 25 -mer and 24mer). Approximately 120 -bp fragments were amplified, purified by electrophoresis, digested by $E c o$ RI and $B a m H I$, and subcloned into pBluescript $\mathrm{SK} /-1$. One dozen clones were randomly picked up and sequenced.

\section{cDNA library screening}

The construction of cDNA libraries was performed as described previously (Kageyama et al. 1991). cDNAs were synthesized by oligo(dT) priming of poly(A) ${ }^{+}$RNAs of rat embryo (E17) and adult whole brain. Double-stranded cDNAs were then constructed, ligated to the EcoRI adaptor (New England Biolabs), and cloned into the EcoRI sites of the $\lambda g t 10$ and $\lambda$ gt 11 vectors. The SacI-KpnI fragment of the plasmid containing HES-1 or HES-3 PCR fragment was used as a probe. For HES-1, six positive clones were obtained by screening $5 \times 10^{5}$ plaques of a $\lambda g t 10$ cDNA library of rat embryo CNS (E17), and the longest insert was subcloned into pBluescript SK $(-)$ at the EcoRI site (pHES-1A). For HES-3, four positive clones were obtained from $1 \times 10^{6}$ plaques of an adult brain $\lambda$ gt $11 \mathrm{cDNA}$ library and were subcloned into the plasmid pHES-3A-pHES-3D

\section{Northern blot analysis}

Five micrograms of poly $(\mathrm{A})^{+}$RNA or $20 \mu \mathrm{g}$ of total RNA was electrophoresed on a formamide/ $1.2 \%$ agarose gel and transferred to a nylon membrane filter (Biodyne, Pall Biosupports). The EcoRI/adaptor)-HincII fragment (646 bp) of pHES-1A and the EcoRI/adaptor-SmaI fragment (713 bp) of pHES-3A were labeled with ${ }^{32} \mathrm{P}$ by the random primer labeling method and used as a probe for HES-1 and HES-3, respectively. The filters were hybridized with the probes overnight at $42^{\circ} \mathrm{C}$ in $50 \%$ formamide, $5 \times$ SSC $(20 \times$ SSC: $3 \mathrm{M} \mathrm{NaCl}-0.3 \mathrm{M}$ sodium citrate), $5 \times$ Denhardt's reagent $(5 \times$ reagent: $0.1 \%$ Ficoll, $0.1 \%$ polyvinylpyrrolidone, $0.1 \%$ bovine serum albumin|, $50 \mathrm{~mm}$ sodium phosphate buffer ( $\mathrm{pH} 6.8), 0.1 \%$ SDS, and $100 \mu \mathrm{g} / \mathrm{ml}$ of heatdenatured salmon sperm DNA. The filters were then washed in $0.1 \times$ SSC and $0.1 \%$ SDS at $65^{\circ} \mathrm{C}$ and exposed to X-ray films for $30 \mathrm{hr}$.

\section{RNase protection assay}

RNase protection assays were performed as described previously (Tsuchida et al. 1990). The Hincll fragment (330 bp) of pHES-1A was subcloned into the EcoRV site of pBluescript $\mathrm{SK} \mid-1$, and a plasmid of the proper insert direction was selected. The EcoRI (adaptor)/EcoRV fragment ( $325 \mathrm{bp}$ ) of pHES-3A was subcloned into the EcoRI-EcoRV sites of the vector. The resulting plasmids were digested with SacI, and the antisense cRNAs were synthesized in the presence of $\left[\alpha_{-}{ }^{32} \mathrm{P}\right] \mathrm{CTP}$ by T7 RNA polymerase. As the synthesized probes contained the multiple cloning site portion of the vector at their $5^{\prime}$ and $3^{\prime}$ ends, their lengths were 443 and 430 bases for HES-1 and HES-3, respec- 
tively. Total RNA ( $30 \mu \mathrm{g}$ ) was hybridized overnight at $45^{\circ} \mathrm{C}$ in $80 \%$ formamide, $0.4 \mathrm{M} \mathrm{NaCl}, 40 \mathrm{mM} \mathrm{l}$, 4-piperazinediethanesulfonate buffer (pH 6.4), and $1 \mathrm{mM}$ EDTA and digested with RNase A and RNase T1. The RNase-resistant products were electrophoresed on a $7 \mathrm{M}$ urea $/ 5 \%$ polyacrylamide gel.

\section{In situ hybridization}

In situ hybridization experiments were performed as described previously (Masu et al. 1991). ${ }^{35} \mathrm{~S}$-Labeled cRNAs corresponding to the EcoRI-SmaI fragment (723 bp) of pHES-1A and the EcoRI-PstI fragment $(676 \mathrm{bp})$ of pHES-3A were synthesized in vitro. These probes were hybridized to $10-\mu \mathrm{m}$ cryostat sections of various tissues.

\section{DNA-binding analysis}

The proteins were prepared as follows. The cDNA fragments of HES-1 (amino acid residues 3-281), E47 (473-end), MyoD (53end), MASH1 (75-end), and ATF2 (77-389) were subcloned into either PGEMEX-1 (Promega) or pMNT T7 expression plasmids. The cDNA fragments used here contained a DNA-binding domain. pMNT was kindly provided by Dr. M. Nishizawa and Professor S. Nagata (Osaka Bioscience Institute, Osaka, Japan). JM109 (DE3) cells transformed by expression plasmids were grown and treated with $1 \mathrm{~mm}$ isopropyl-1-thio- $\beta$-D-galactopyranoside for $2 \mathrm{hr}$. The cells were collected and suspended in 0.02 volume of $30 \mathrm{~mm}$ Tris- $\mathrm{HCl}(\mathrm{pH} \mathrm{7.5)}, 1 \mathrm{~mm}$ EDTA, and $20 \%$ (vol/vol) sucrose. The proteins were purified from the SDSpolyacrylamide gel, incubated in $6 \mathrm{M}$ guanidine- $\mathrm{HCl}$ for $20 \mathrm{~min}$, and dialyzed against $0.1 \mathrm{M} \mathrm{KCl} / \mathrm{HM}$ [20 mM HEPES at pH 7.9, 1 $\mathrm{mM} \mathrm{MgCl} 2,2 \mathrm{~mm}$ dithiothreitol, and $17 \%$ (vol/vol) glycerol) at $4^{\circ} \mathrm{C}$ for $8 \mathrm{hr}$.

The probe DNAs were prepared as follows. For the $\mathrm{N}$ box and E box ( $\mathrm{KE} 2$ ) probes, the double-stranded oligonucleotide fragment, containing either two $\mathrm{N}$ boxes (CGGCACAAGGC and GCCACGAGTG| present in the promoter region of the $E(s p l)$ $m 8$ gene or two repeats of $\kappa$ E2 sites (AGGCAGGTGGCC), was cloned into the EcoRI site of pBluescript II SK(-|-|Stratagene), and the XhoI-SacII fragment labeled at the XhoI site was isolated. For the CRE probe, the HinfI-PmaCI fragment of the PPT-A gene promoter labeled at the Hinfl site was isolated (Kageyama et al. 1991).

The DNase I footprinting reactions were carried out in a total volume of $50 \mu \mathrm{l}$ containing $5 \mathrm{ng}$ of the probe, as described previously (Dynan and Tiian 1983).

The gel mobility-shift assay with the $E(s p l) \mathrm{N}$ box or the MCK enhancer sequence was carried out as described previously (Benezra et al. 1990; Johnson et al. 1992; Tietze et al. 1992). For N box binding, a double-stranded oligonucleotide (top strand, 5'CTAGACGCCACGAGCCACAAGGATTG-3'; bottom strand, 5'-CTAGCAATCCTTGTGGCTCGTGGCGT-3') was labeled at both ends by filling in with Klenow enzyme in the presence of $\left[\alpha^{-32} \mathrm{P}\right] \mathrm{dCTP}$ and used as a probe. The mutations were introduced into both the CACGAG and CACAAG sequences, as indicated in Figure 8A.

\section{CAT analysis and myogenic conversion assay}

For the CAT reporter plasmid, the double-stranded oligonucleotide fragment containing either six repeats of the $\mathrm{N}$ boxes (three repeats of CCACGAGCCACAAGG for the wild type; three repeats of CCATGAGCCATAAGG for the mutated $N$ box) or seven repeats of the $\mathrm{E}$ boxes ( $\mathrm{\kappa E} 2$ site) (AGGCAGGTGGC) was cloned into the XhoI site $(-273$ relative to the transcription initiation site) of the $\beta$-actin CAT plasmid.
For eukaryotic expression plasmids, full-length cDNA fragments of HES-1 and HES-3 were subcloned into the eukaryotic expression vector containing the CMV promoter pSV-CMV. Full-length E47 and MASH1 cDNAs were cloned from the human brain cDNA library and rat embryonal CNS library, respectively, and inserted into $\mathrm{pSV}-\mathrm{CMV}$. The E47 expression vector was also kindly provided by Dr. D. Baltimore (The Rockefeller University, New York). No difference was observed between the two clones. The MyoD expression vector driven by the $\beta$-actin promoter and the CAT reporter plasmid containing the MCK enhancer and the thymidine kinase promoter were kindly provided by Drs. Y. Nabeshima and A. Fujisawa (Fujisawa-Sehara et al. 1990).

The CAT reporter $(2 \mu \mathrm{g})$ and the eukaryotic expression plasmids $(8 \mu \mathrm{g}$ each) were cotransfected into NIH-3T3 cells using the calcium phosphate coprecipitation method. Two micrograms of $\mathrm{pCDM} 8-\beta$-gal, a $\beta$-galactosidase gene expression vector driven by the CMV promoter, was also cotransfected to evaluate transfection efficiency. The total DNA amounts were adjusted to $22 \mu \mathrm{g}$ with $\mathrm{pSV}-\mathrm{CMV}$. CAT activities were determined, as described previously (Gorman et al. 1982). We used 1-deoxy [dichloroacetyl-1-14 C] chloramphenicol (Amersham) as CAT substrate.

The CAT assays with MyoD and MASH1 and the myogenic conversion assay using $10 \mathrm{Tl} / 2$ cells were carried out as described previously (Wright et al. 1989; Benezra et al. 1990; Johnson et al. 1992).

\section{Acknowledgments}

We thank Professor Noboru Mizuno for his kind help with in situ hybridization experiments, Akira Uesugi and Dr. Chihiro Akazawa for photographic assistance, Drs. Elizabeth Knust and Jose A. Campos-Ortega for communicating their unpublished results, Dr. Shinii Fushiki for useful discussion, Dr. Mikio Nishizawa and Professor Shigekazu Nagata for pMNT, Dr. David Baltimore for the E47 expression vector, Drs. Yoichiro Nabeshima and Atsuko Fujisawa for the MyoD expression vector and the reporter plasmid with the MCK enhancer, and Dr. Makoto Ishibashi for his help in isolating the human E47 cDNA clone. This work was supported in part by research grants from the Ministry of Education, Science, and Culture of Japan.

The publication costs of this article were defrayed in part by payment of page charges. This article must theefore be hereby marked "advertisement" in accordance with 18 USC section 1734 solely to indicate this fact.

\section{Note added in proof}

The nucleotide sequence data reported in this paper will appear in the DDBJ, EMBL, and GenBank data libraries under accession numbers D13417 and D13418.

\section{References}

Balling, R., U. Deutsch, and P. Gruss. 1988. undulated, a mutation affecting the development of mouse skeleton, has a point mutation in the paired box of Pax 1. Cell 55: 531-535.

Benezra, R., R.L. Davis, D. Lockshon, D.L. Turner, and H. Weintraub. 1990. The protein Id: A negative regulator of helixloop-helix DNA binding proteins. Cell 61: 49-59.

Blackwell, T.K. and H. Weintraub. 1990. Differences and similarities in DNA-binding preferences of MyoD and E2A protein complexes revealed by binding site selection. Science 250: 1104-1110. 
Botas, J., J.M. del Prado, and A. Gárcia-Bellido. 1982. Gene-dose titration analysis in the search of trans-regulatory genes in Drosophila. EMBO J. 1: 307-310.

Buckingham, M. 1992. Making muscle in mammals. Trends Genet. 8: 144-149.

Campos-Ortega, J.A. and E. Knust. 1990. Molecular analysis of a cellular decision during embryonic development of Drosophila melanogaster: Epidermogenesis or neurogenesis. Eur. J. Biochem. 190: 1-10.

Carroll, S.B., A. Laughon, and B.S. Thalley. 1988. Expression, function, and regulation of the hairy segmentation protein in Drosophila embryo. Genes \& Dev. 2: 883-890.

Carroll, S.B. and J.S. Whyte. 1989. The role of the hairy gene during Drosophila morphogenesis: Stripes in imaginal discs. Genes \& Dev. 3: 905-916.

Caudy, M., H. Vässin, M. Brand, R. Tuma, L.Y. Jan, and Y.N. Jan. 1988. daughterless, a Drosophila gene essential for both neurogenesis and sex determination, has sequence similarities to myc and achaete-scute complex. Cell 55: 1061-1067.

Christy, B.A., L.K. Sanders, L.F. Lau, N.G. Copeland, N.A. Jenkins, and D. Nathans. 1991. An Id-related helix-loop-helix protein encoded by a growth factor-inducible gene. Proc. Natl. Acad. Sci. 88: 1815-1819.

Courey, A.J. and R. Tjian. 1988. Analysis of SP1 in vivo reveals multiple transcriptional domains, including a novel glutamine-rich activation motif. Cell 55: 887-898.

Davis, R.L., H. Weintraub, and A.B. Lassar. 1987. Expression of a single transfected cDNA converts fibroblasts to myoblasts. Cell 51: 987-1000.

Davis, R.L., P.-F. Cheng, A.B. Lassar, and H. Weintraub. 1990 The MyoD DNA binding domain contains a recognition code for muscle-specific gene activation. Cell 60: 733-746.

De Robertis, E.M., G. Oliver, and C.V.E. Wright. 1990. Homeobox genes and the vertebrate body plan. Sci. Am 263(1): 26-32.

Dynan, W.S. and R. Tjian. 1983. The promoter-specific transcription factor $\mathrm{Spl}$ binds to upstream sequence in the SV40 early promoter. Cell 35: 79-87.

Ellis, H.M., D.R. Spann, and J.W. Posakony. 1990. extramacrochaetae, a negative regulator of sensory organ development in Drosophila, defines a new class of helix-loop-helix proteins. Cell 61: 27-38.

Fujisawa-Sehara, A., Y. Nabeshima, Y. Hosoda, T. Obinata, and Y. Nabeshima. 1990. Myogenin contains two domains conserved among myogenic factors. J. Biol. Chem. 265: 1521915223.

Fujita, S. 1963. The matrix cell and cytogenesis in the developing central nervous system. J. Comp. Neurol. 120: 37-42.

Garrell, J. and J. Modolell. 1990. The Drosophila extramacrochaetae locus, an antagonist of proneural genes that, like these genes, encodes a helix-loop-helix protein. Cell 62: 3948.

Gehring, W.J. 1987. Homeo boxes in the study of development. Science 236: 1245-1252.

Gilbert, S.F. 1991. Early vertebrate development: neurulation and ectoderm. In Developmental biology, 3rd ed., pp. 155172. (Sinauer Associates, Sunderland, MA).

Gorman, C.M., L.F. Moffat, and B.H. Howard. 1982. Recombinant genomes which express chloramphenicol acetyltrans ferase in mammalian cells. Mol. Cell. Biol. 2: 1044-1051.

Greene, L.A. and A.S. Tischler. 1976. Establishment of a norad renergic clonal line of rat adrenal pheochromocytoma cells which respond to nerve growth factor. Proc. Natl. Acad. Sci. 73: 2424-2428.

Gruss, P. and C. Walther. 1992. Pax in development. Cell 69: 719-722
Hooper, K.L., S.H. Parkhurst, and D. Ish-Horowicz . 1989. Spatial control of hairy protein expression during embryogenesis. Development 107: 489-504.

Ingham, P.W., K.R. Howard, and D. Ish-Horowicz. 1985. Transcription pattern of the Drosophila segmentation gene hairy. Nature 318: 439-445.

Ito, M. 1984. Purkinje cells: morphology and development. In The cerebellum and Neural Control, pp. 24-25. (Raven Press, New York).

Jan, Y.N. and L.Y. Jan. 1990. Genes required for specifying cell fates in Drosophila embryonic sensory nervous system. Trends Neurosci. 13: 493-498.

Johnson, J.E., S.J. Birren, and D.J. Anderson. 1990. Two rat homologues of Drosophila achaete-scute specifically expressed in neuronal precursors. Nature 346: 858-861.

Johnson, J.E., S.J. Birren, T. Saito, and D.J. Anderson. 1992. DNA binding and transcriptional regulatory activity of mammalian achaete-scute homologous (MASH) proteins revealed by interaction with a muscle-specific enhancer. Proc. Natl. Acad. Sci. 89: 3596-3600.

Kageyama, R., Y. Sasai, and S. Nakanishi. 1991. Molecular characterization of transcription factors that bind to the cAMP responsive region of the substance $\mathrm{P}$ precursor gene. $/$. Biol. Chem. 266: 15525-15531.

Kania, M.A., A.S. Bonner, J.B. Duffy, and J.P. Gergen. 1990. The Drosophila segmentation gene runt encodes a novel nuclear regulatory protein that is also expressed in the developing nervous system. Genes \& Dev. 4: 1701-1713.

Kessel, M. and P. Gruss. 1990. Murine developmental control genes. Science 249: 374-379.

Klämbt, C., E. Knust, K. Tietze, and J.A. Campos-Ortega. 1989. Closely related transcripts encoded by the neurogenic gene complex Enhancer of split of Drosophila melanogaster. $E M B O$ I. 8: 203-210.

Kohl, N.E., E. Legouy, R.A. DePinho, P.D. Nisen, R.K. Smith, C.E. Gee, and F.W. Alt. 1986. Human N-myc is closely related in organization and nucleotide sequence to c-myc. $\mathrm{Na}$ ture 319: 73-77.

Lee, C.C., X. Wu, R.A. Gibbs, R.G. Cook, D.M. Muzny, and C.T. Caskey. 1988. Generation of cDNA probes directed by amino acid sequence: Cloning of urate oxidase. Science 239: 1288-1291.

Lo, L.-C., J.E. Johnson, C.W. Wuenschell, T. Saito, and D.J. Anderson. 1991. Mammalian achaete-scute homolog 1 is transiently expressed by spatially restricted subsets of early neuroepithelial and neural crest cells. Genes \& Dev. 5: 1524-1537.

Masu, M., T. Tanabe, K. Tsuchida, R. Shigemoto, and S. Nakanishi. 1991. Sequence and expression of a metabotropic glutamate receptor. Nature 349: 760-765.

Mermod, N., E.A. O'Neill, T.J. Kelly, and R. Tjian. 1989. The proline-rich transcriptional activator of CTF/NF-1 is distinct from the replication and DNA binding domain. Cell 58: 741-753.

Murre, C., P.S. McCaw, and D. Baltimore. 1989. A new DNA binding and dimerization motif in immunoglobulin enhancer binding, daughterless, $M y o D$, and myc proteins. Cell 56: 777-783.

Nelson, C., L.-P. Shen, A. Meister, E. Fodor, and W.J. Rutter. 1990. Pan: A transcriptional regulator that binds chymotrypsin, insulin, and AP-4 enhancer motifs. Genes \& Dev. 4: $1035-1043$.

Rosenfeld, M.G. 1991. Pou-domain transcription factors: pouer-ful developmental regulators. Genes \& Dev. 5: 897-907.

Rudnicki, M.A., and M.W. McBurney. 1987. Cell culture methods and induction of differentiation of embryonal carcinoma 
Sasai et al.

cell lines. In Teratocarcinomas and embryonic stem cells (ed. E. J. Robertson), pp. 19-49. IRL Press, Oxford, England.

Rushlow, C.A., A. Hogan, S.M. Pinchin, K.M. Howe, M. Lardelli, and D. Ish-Horowicz, D. 1989. The Drosophila hairy protein acts in both segmentation and bristle patterning and shows homology to N-myc. EMBO I. 8: 3095-3103.

Saiki, R.K., D.H. Gelfand, S. Stoffel, S. Scharf, R. Higuchi, G.T. Horn, K.B. Mullis, and H.A. Erlich. 1988. Primer-directed enzymatic amplification of DNA with a thermostable DNA polymerase. Science 239: 487-491.

Skeath, J.B. and S.B. Carroll. 1991. Regulation of achaete-scute gene expression and sensory organ pattern formation in the Drosophila wing. Genes \& Dev. 5: 984-995.

Tapscott, S.J., R.L. Davis, M.J. Thayer, P.-F. Cheng, H. Weintraub, and A.B. Lassar. 1988. MyoDl: A nuclear phosphoprotein requiring a myc homology region to convert fibroblasts to myoblasts. Science 242: 405-411.

Taylor, S.M. and P.A. Jones. 1979. Multiple new phenotype induced in $10 \mathrm{~T} 1 / 2$ and $3 \mathrm{~T} 3$ cells treated with 5-azacytidine. Cell 17: 771-779.

Tietze, K., N. Oellers, and E. Knust. 1992. Enhancer of split ${ }^{\mathrm{D}}$. A dominant mutation of Drosophila, and its use in the study of functional domains of a helix-loop-helix protein. Proc. Natl. Acad. Sci. 89: 6152-6156.

Tsuchida, K., R. Shigemoto, Y. Yokota, and S. Nakanishi. 1990. Tissue distribution and quantitation of the mRNAs for three rat tachykinin receptors. Eur. I. Biochem. 193: 751-757.

Vaessin, H., M. Caudy, E. Bier, L.Y. Jan, and Y.N. Jan. 1990. Role of helix-loop-helix proteins in Drosophila neurogenesis. Cold Spring Harbor Symp. on Quant. Biol. 55: 239-245.

Villares, R. and C.V. Cabrera. 1987. The achaete-scute gene complex of D. melanogaster: Conserved domains in a subset of genes required for neurogenesis and their homology to myc. Cell 50: 415-424.

Weintraub, H., R. Davis, S. Tapscott, M. Thayer, M. Krause, R. Benezra, T.K. Blackwell, D. Turner, R. Rupp, S. Hollenberg, Y. Zhuang, and A. Lasser. 1991. The MyoD gene family: Nodal point during specification of the muscle cell lineage. Science 251: 761-766.

Wright, W.E., D.A. Sassoon, and V.K. Lin. 1989. Myogenin, a factor regulating myogenesis, has a domain homologous to MyoD. Cell 56: 607-617

Xiao, J.H., I. Davidson, H. Matthes, J.-M. Garnier, and P. Chambon. 1991. Cloning, expression, and transcriptional properties of the human enhancer factor TEF-1. Cell 65: 551-568. 


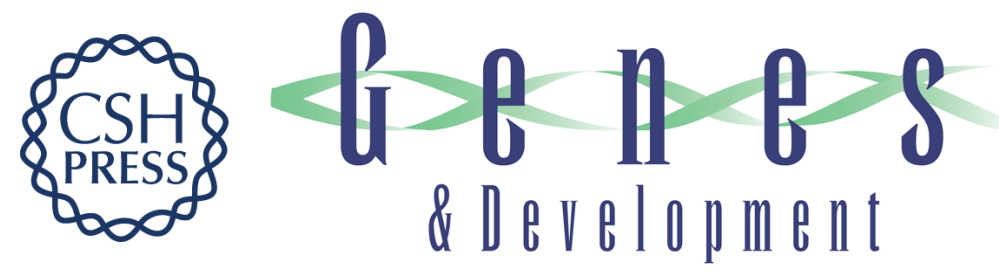

\section{Two mammalian helix-loop-helix factors structurally related to Drosophila hairy and Enhancer of split.}

Y Sasai, R Kageyama, Y Tagawa, et al.

Genes Dev. 1992, 6:

Access the most recent version at doi:10.1101/gad.6.12b.2620

References This article cites 52 articles, 22 of which can be accessed free at:

http://genesdev.cshlp.org/content/6/12b/2620.full.html\#ref-list-1

License

Email Alerting

Service

Receive free email alerts when new articles cite this article - sign up in the box at the top right corner of the article or click here.

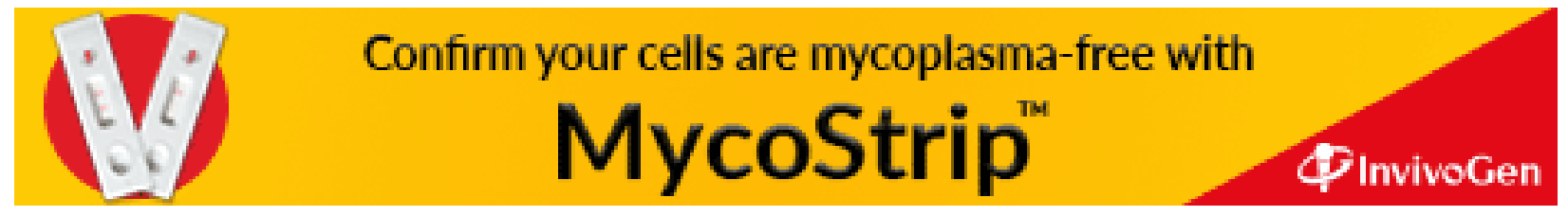

